\title{
Gender in the Teaching Profession: University Students' Views of Teaching as a Career ${ }^{1}$
}

\author{
Veronika TAŠNeR ${ }^{\star 2}$, MOJCA Žveglič MiHelič ${ }^{3}$ AND \\ MetKa Mencin ČeplaK ${ }^{4}$
}

$\approx$ The purpose of our research is to gain a better insight into what encourages young adults, in particular young women, to enter the teaching profession. The empirical part of the article is based on a pilot study including 132 students, with data collection being based on a survey approach using a questionnaire. The research attempts to address the context from which the desired characteristics of pre-service teachers with regard to their future employment arise. We have therefore tried to single out factors influencing the choice of teaching as a career, and to examine pre-service teachers' attitudes towards the reputation of female and male teachers. The data obtained confirm the thesis that the predominance of women in the teaching profession(s) is an effect of the harmonisation of the female respondents' habitus and their perception of the field they are entering. The perception of the teaching profession as a vocation (calling) that can be linked to the concepts of caring, giving and helping also proves to be very important. The data also confirms the thesis that the orientation towards life and work balance is important to our respondents of both genders.

Keywords: gender, habitus, field, teaching as a career, vocation

1 In our paper we address the so-called feminisation of the teaching profession, which presupposes a binary gender classification. We therefore use the wording "both genders", although we are aware of the plurality of genders that reaches beyond the socially dominant gender binarism.

$2{ }^{*}$ Corresponding Author. University of Ljubljana, Faculty of Education, Slovenia; veronika. tasner@pef.uni-lj.si.

3 University of Ljubljana, Faculty of Education, Slovenia.

4 University of Ljubljana, Faculty of Social Sciences, Slovenia. 


\section{Spol in učiteljstvo: pogledi univerzitetnih študentk_ov na učiteljski poklic ${ }^{5}$}

Veronika Tašner, Mojca Žveglič Mihelič in Metka Mencin Čeplak

$\approx$ Namen naše raziskave je zagotoviti boljši vpogled v razloge, zaradi katerih se mladi odrasli, predvsem mlade ženske, odločajo za učiteljski poklic. Empirični del članka temelji na pilotni študiji, ki vključuje 132 študentk_ ov pedagoške fakultete, podatki pa so zbrani s pomočjo vprašalnika. Z raziskavo smo poskušale analizirati, katere značilnosti bodočega poklica so za anketirane najbolj zaželene. S pomočjo tega smo poskušale identificirati dejavnike izbire učiteljskega poklica, posebej pa smo ugotavljale, kako repondentke_i percipirajo ugled učiteljic_ev. Rezultati so potrdili hipotezo, da je številčna prevlada žensk v učiteljskih poklicih učinek harmonizacije percepcije polja, v katerega stopajo respondentke (tj. učiteljskega poklica) s svojim habitusom. Pri tem se je kot posebej pomembna izkazala percepcija učiteljskega poklica kot poklicanosti, ki jo je mogoče povezati s koncepti skrbi, dajanja in pomoči. Rezultati potrjujejo tudi tezo, da je možnost usklajevanja zasebnega življenja in poklicnega dela pomembna za vse repondentke_e ne glede na spol.

Ključne besede: spol, habitus, polje, poučevanje kot poklic

5 Tema našega prispevka se nanaša na t.i. feminizacijo učiteljskega poklica, ki predpostvalja binarno spolno delitev, zato uporabljamo konvencionalni termin "oba spola", a se zavedamo pluralnosti oziroma mnogoterosti spolov, ki presegajo družbeno prevladujoč spolni binarizem. 


\section{Introduction}

In the literature on gender and education, the theme of the teaching profession as a highly gendered profession has a significant place. One of the topical subjects in current debates remains the question of why the decision to enter teaching as a career remains so gendered, just as it does in certain others professions (Asimaki \& Vergidis, 2013; Bourdieu, 2001; Drudy, 2008; Richardson \& Watt, 2006; Riddell \& Tett, 2006). International data for EU countries show that in most European countries women continue to (numerically) dominate primary teaching. In lower secondary education (ISCED level 2) in the EU as a whole, the great majority of teachers are still women, with less than one third being men. "In individual countries, the proportional gender imbalance is highest in Bulgaria, Estonia, Latvia, and Lithuania, in which less than $20 \%$ of teachers are men. Only in the Netherlands are the proportions of women and men teachers roughly the same, while in Spain and Luxembourg the percentage point difference between them is 15.5 and 13.6, respectively" (European Commission/ EACEA/Eurydice, 2015, p. 19).

In Slovenia, the highest proportional gender imbalance is generally in primary schools and primary schools with an adapted programme: at the end of the $2014 / 15$ school year, 16,014 teachers took part in the pedagogical process, $88 \%$ of whom were women. In secondary schools, the ratio between men and women is more balanced: 6,088 teachers were employed in the 2013/14 school year, $66 \%$ of whom were women. Men still prevail among tertiary (higher) education teachers, while the ratio between men and women is equal among teachers at short-cycle college. In the 2015/16 academic year, the percentage of men (59.7\%) among higher education teachers was higher than women (40.3\%). The percentage of women teachers in higher education is, however, slowly increasing (in the 2007/08 academic year, only $33.8 \%$ of higher education teachers were female). In higher vocational colleges, the ratio between men and women is almost equal (48\% women and 52\% men) (SORS, 2017).

Analyses of the historical conditions for the entry of women to the teaching profession in Europe, USA and Canada present several factors explaining why the teaching profession, which was, until the second half of the nineteenth century, reserved for men (with rare exceptions in convents), opened up for women:

- $\quad$ numerous new professions developed with the onset of industrialisation;

- the extension of obligatory primary education demanded a greater number of teachers;

- women, especially unmarried women, were a cheaper labour force than 
men, which was one of the reasons for the enactment of celibacy in many countries (e.g., Acker, 1995), including Slovenia (Milharčič Hladnik, 1995; Mrgole Jukić , 1998);

- $\quad$ after "human nature" became an object of scientific enquiry in the nineteenth century, the female intellect was "discovered", which at least conditionally allowed women to "compete" with men (Walkerdine, 1989; 1990).

In Slovenia, as in many countries, the teaching profession was one of the first to become accessible to women, who were allowed to enter the labour market. In 1869, the Habsburg Monarchy passed the Primary Education Act, which prolonged obligatory primary schooling to eight years and declared the formal equality of female and male teachers paid by the state. Some years after this Act came into force, the first female college of education was established (1871), which was at the same time the first public education institution that allowed women a higher education (Milharčič Hladnik, 1995). Only a few decades later, women already prevailed among primary teachers. However, despite their statutorily defined equality, the status of women was essentially different to that of men: they were not only paid less, but were also more highly supervised than men (until 1918, they were obliged by law to practise celibacy) (ibid.). Despite this (or better: partly because of this), female teachers were the bearers of important social changes in the field of political and other rights of women and girls, not only in the teaching profession. Female teachers were the most educated women and were aware of the position of women in society. It therefore comes as no surprise that they were the first to strive for the right of female teachers to vote. After the demand of the Catholic journal Slovenian Teacher in 1901, the Society of Slovenian Female Teachers followed suit later the same year. The demand for the right of female teachers to vote later grew into the demand for voting rights to for all women (Antić Gaber, Rožman \& Selišnik, 2009). As Milharčič Hladnik (1995) stresses, although female teachers in the nineteenth century were respected, they were also subject to suspicion and resistance, as education was presented as a threat to the fulfilment of the natural roles of women, and to the earnings of men: at that time, women were still employed mainly because their work was cheaper.

Today, women still prevail in teaching professions, which could be attributed to a number of demographic, economic, political and cultural factors: the need for teachers due to demographical factors, the accessibility of education, meritocracy, the general employment possibilities, the possibility of reconciling professional and family work, the regulation of maternity leave and leave for childcare, etc. (Acker, 1995). In Slovenia, another factor is that teaching represents relative secure employment due to the vast network of public nursery 
schools and schools, and to the relatively small gap between the needs of employers and the number of adequately educated candidates.

\section{Theoretical Framework}

The purpose of the present study is to gain a better insight into the reasons for young adults deciding to enter the teaching profession. The empirical part of the article is based on a pilot study that included 132 students. The study tried to answer questions regarding who decides to become a teacher and why. It is assumed that the answers to these questions enable further reflection on the social reproduction of the gendering of the teaching profession. At this point, we are particularly intrigued by the fact that women, despite the wider spectrum of available choice, choose gender-marked professions. Statistical data suggest that young women are more successful in finishing secondary and tertiary education, while also confirming the hypothesis on the breakthrough of women into prestigious scientific disciplines such as medicine and law. At the same time, a thorough survey of the data confirms the old hypothesis of the gender-specific educational paths of men and women. The majority of women still decide for "typically female" fields of study, such as education, the humanities, social sciences, social welfare and healthcare, while men remain prevalent in "traditionally male" programmes, such as computer science, mathematics, natural sciences, technical sciences, construction, and production and processing technology (Tašner \& Rožman, 2015). On these grounds, we follow the hypothesis that choices of study programmes, which exist within the framework of conventional images of femininity and masculinity, result from habitus and practices (Bourdieu, 2001) that still control the processes of their identification and subjectivation. We must stress that the fact that women still prevail numerically in the teaching profession is not a social problem. It would, however, be a social problem if it demonstrated that their choice is gender determined or the result of "a voluntary subjection" (Beauvois, 200o) to the social expectations and possibilities of the labour market. Feminist analyses explain the predominance of women in most of the lower stages of education and teaching with the interpretation that these professions, to some extent, represent an extension of the work women traditionally perform at home. The younger the children are, the more working with them is associated with caring and the less with teaching (e.g., Skelton, 2009), while caring professions are still regarded as female-adequate professions (e.g., Acker, 1995; Walkerdine, 1994). In her extensive inquiry of discourses and studies on the "conflation of teaching and mothering", Acker reminds readers of the discussion that, as early as in the nineteenth century in the USA, promoted the 
realisation of "natural mothering" in the classroom (Dehli, 1994 and Steedman, 1984 in Acker, 1995, p. 121). The conviction about the conflation of teaching and mothering does not only control everyday, patriarchal common sense discourses, but also (feminist) scientific discussions, especially discussions on the ethics of care, which essentially focus on care for dependent and vulnerable human beings and support of social relations in a way that ensures the wellbeing of caregivers and care-receivers. The ethics of care had already been discussed by Mary Wollstonecraft, and in the works of Carol Gilligan and Nel Noddings at the beginning of the 1980s it became one of the widespread "truths about women", as it was above all believed to be characteristic of them (Acker, 1995). Some female authors ascribe this to female "nature", while others present it as a survival strategy, and thus as a response to the subordination of women (Hare-Mustin and Marecek, 1990 in Acker, 1995, p. 120). Caring as a "fundamental female characteristic" also finds expression in teaching, which, especially in the earliest period, protects the child, his or her needs and demands, and contributes to his or her wellbeing. The (female) teacher's task is to respect the child's or pupil's freedom, creativity and spontaneity (e.g., Noddings, 1992; 1996). These principles and practices are close to those of the (still) current child-centred pedagogy that treats the child/pupil as a self-regulating and rational individual and promotes democracy and freedom. All of this demands from the teacher a tutoring, stimulating and directing role, and presupposes his or her understanding of and loving reaction to the child's/ pupil's needs. As Walkerdine (1990) warns, child-centred pedagogy primarily addresses women, as it presupposes an active, free, autonomous, omnipotent and essentially male child, and a passive female teacher. This "motherhood imagery" (Acker, 1995) thus addresses mainly women and structures their representations of professions and teachings appropriate for them. Acker summarises the results of research on "motherhood imagery" in teaching practices, which indicate that it is mainly female teachers, obliged to "their" community (older teachers, teachers from marginalised groups) who are bound to this imaginary. The warning that this imaginary is "embedded in the nature of elementary school teaching" is therefore highly pertinent: the imagery is embodied by the one-teacher-to-oneclassroom system that is typical for the first years of schooling, as it stimulates "motherlike intense attachments and dedication elementary teachers show for their classes" (Kidder, 1989 and McPherson, 1972 in Acker, 1995, p. 121).

To conclude with Acker (1995, pp. 123-124):

Teachers' caring activities, then, have from one perspective been seen as derived from their teacher identities and the nature of their work; from another, as a valued part of "women's ways"; from a third, as a means to improve children's futures; and, from a fourth, as a consequence of the social 
expectations that women's caring work should blur the distinction between labour and love. The place of caring in teachers' work remains deeply contradictory, simultaneously the moral high ground of the teaching task and a prime site of women's oppression.

It is possible to link Acker's thematisations with Bourdieu's categorical apparatus, which enables us to consider the relations of the social world, as it surpasses the divide objective/subjective, individual/society, structure/action. According to Bourdieu, it is relationism and not substantialism that enables us to think and understand social phenomena. In the present paper, we search for the reasons why it is mainly young women who still decide to enter professions in the field of education en masse, despite many other options being open to them. We also search for reasons for the choice of this profession among men. In answering these questions, we will refer to Bourdieu's concepts of field, (gender) habitus and practices.

The concept of habitus is one of the key concepts in Bourdieu's reflexive approach to social life. Habitus represents "systems of durable, transposable dispositions, structured structures predisposed to function as structuring structures (...) principles which generate and organize practices and representations" (Bourdieu, 1990, p. 53). We could say that habitus functions as the agent's second nature: it enables the individual to be, to feel, to think, to (re)act in the social world, etc. On the one hand, habitus is influenced by the social realm, but it also structures the world of each individual. In other words, Bourdieu treats social life as "a mutually constituting interaction of structures, dispositions, and actions whereby social structures and embodied (therefore situated) knowledge of those structures produce enduring orientations to action which, in turn, are constitutive of social structures" (Postone, Calhun \& LiPuma, 1993, p. 4).

With the notion of gender habitus, Bourdieu (2001) explains differences between men and women. These differences are made through female and male bodies, which are socially constructed; the differences are then naturalised, which is where masculine domination draws its legitimation from (ibid.). For Bourdieu, gender is a social construct and gender habitus is far from only a biological category; it represents an entity that is "complex, historical and fundamentally cultural in form" (Dillabough, 2004, p. 496). According to Bourdieu, the social reality is constructed by a division of things and activities in line with binary classifications, of which sex division (male and female) is one of the crucial ones. These arbitrary divisions are then naturalised and understood as "normal, natural, inevitable" (Bourdieu 2001, p. 8). In this way, we can talk about female habitus, which takes a personal form and shapes each individual from her (his) earliest beginnings. 
Gender habitus thus ranks among the "fundamental elements of the individual's identity" (Krais, 2006, p. 121). It significantly defines the individual self; it is seen as "pure nature". If we try to explain sexual identity with Bourdieu's concepts, we can say that it represents far more than incorporated representations of the outside world in the agent. The process goes on at the pre-reflexive level: it presents incorporation as practical adaptation. Sexual identity is not a mechanical and deterministic structure; it is an open system of dispositions, of regulated freedoms, which are “durable but not eternal" (Bourdieu \& Wacquant, 1996, p. 133).

Discussing gender issues, the concept of field, by which social agents are defined in "terms of the positions and interests that arise from the different distribution of specific resources in each field and in the global social field" (Costa, 2006, p. 876), is also significant. Field as a system of positions and relationships between positions is as crucial for the social agent as habitus. In the practice of the social agent, they are not separated. The relationship between field and habitus is the relationship between "social structures and mental structures" (Bourdieu \& Wacquant, 1996, p. 140). The social cosmos is sub-structured by fields or microcosms (political, economic, educational, religious, etc.) and may be defined as "a network, or configuration, of objective relations between positions" (Bourdieu \& Wacquant, 1996, p. 97). Each field is characterised by its determinate agents (politicians, students, journalists, scientists, teachers, etc.), accumulation of history, logic of action, and forms of capital. Fields are not completely autonomous; they are only relatively delineated and they position themselves in relation to each other. Just as it takes place between fields, struggle and positioning also occurs within the specific field on the part of the agents. The position of an agent in a field is defined by the quantity and quality of different forms of capital linked to the habitus. Capital acquired in one field is transferable to another field. The quantity of capital changes in time, depending on the habitus of the agents and their life trajectories.

When discussing women's choices of profession, in our case teaching, it is therefore important to have in mind relations between the logic of and positioning in the specific field and dispositions of women. Or, as Asimaki and Vergidis point: "based on the shaped habitus of women which are compatible with the dominant social theory, women seek, in the world of work, 'small professions' avoiding positions of power and prestige, fully in harmony with 'their natural inclinations' in professional fields where men usually exercise power and women are restricted to offering service" (2013, p. 143). All with the help of symbolic violence, "a gentle violence, imperceptible and invisible even to its victims" (Bourdieu, 2001, p. 1) exercised through the means of "communication and cognition (...) recognition, or even feeling" (ibid., p. 2). 


\section{Subject of the Research}

The present research focuses on pre-service teachers (to be referred to as "students") and addresses the following contexts: (i) the desirable characteristics of their future employment; (ii) the factors influencing their choice of teaching as a career; and (iii) their attitudes towards the reputation of female and male teachers. We aim to answer the following research questions:

1. What are the desirable characteristics of students' future employment?

2. Which deciding factors are at play in students' choice of a teaching profession?

3. What are students' attitudes towards the reputation of female and male teachers?

4. Are there significant differences between female and male students in terms of the answers to questions $1-3$ ?

5. Are there significant differences between Primary Education students and Two-Subject Teacher students in terms of the answers to questions 1-3?

\section{Method}

The research reported in the present paper is a pilot study and as such prepares the ground for the further development of the instruments and data collection strategies. Data collection in our pilot study was based on a survey approach using a questionnaire.

Sample: The research was conducted on 132 students at the Faculty of Education of the University of Ljubljana in the 2015/16 academic year. Of these students, 67 were fourth-year students of the first-cycle study programme Primary Education ( $75.3 \%$ of the whole generation at the faculty) and 65 were third-year students of the first-cycle study programme Two-Subject Teacher $(80.2 \%$ of the whole generation at the faculty). All of the Primary Education students were females, while the group of Two-Subject Teacher students consisted of $72.3 \%$ females and $27.3 \%$ males. ${ }^{6}$ The students participating in the research were aged 21- 26 years $($ mean $=22.29, \mathrm{SD}=0.99$ ), and predominantly resided in the Central Slovenian region $(31.1 \%)$, the South-Eastern Slovenian region $(20.5 \%)$ and the Gorenjska (North-Western Slovenian) region; 17.4\%). The largest share resided in village-size settlements with up to 3,000 residents $(48.1 \%)$, almost a quarter lived in a town with 3,000-15,000 residents (23.7\%), and the third largest group was those residing in cities with $15,000-100,000$ residents $(21.4 \%)$. Only $6.9 \%$ of

6 In the questionnaire, the students were offered three categories to express their gender: "female", "male" and "other". 
the participants resided in larger cities with more than 100,000 residents. The study programme they were enrolled in was the first choice for $67.4 \%$ of the participants, while the first choice of $14.5 \%$ of the students was another study programme at the same faculty. For the remainder of the students, their first choice was to study at another faculty.

The largest share of the students' fathers had completed vocational school (30.3\%), or professional college or university $(23.5 \%)$, followed by secondary technical school (22.7\%). A quarter of the students' mothers had completed professional college or university (26.5\%), 23.5\% had completed vocational school, and a fifth had completed secondary technical school (20.5\%). More than half of the students' fathers were employed in the fields of engineering, production technology and construction (54.0\%), followed by the services sector (16.7\%) and the field of social sciences, business or administrative sciences, or law (12.7\%); the largest share of the fathers worked in the private sector $(47.2 \%)$. The students' mothers' professions were typically from the field of social sciences, business or administrative sciences, or law (25.8\%), followed by the services sector $(20.3 \%)$ and the field of education (14.8\%); more than half of the mothers worked in the public sector (52.3\%).

Instrument: The questionnaire consists of two scales. The Desirable Employment scale is designed to measure students' desires in terms of their future employment. It consists of 11 statements, which are assessed using descriptive rating scales with five response anchors: "very important", "important", "neither important nor unimportant", "unimportant", "not at all important". The scale contains two sub-scales: Caring and Benefits. The Deciding Factors scale is meant to measure the students' perception of the importance of different reasons in choosing a teaching profession. It includes 18 statements assessed using descriptive rating scales with six response anchors: "very true of me", "true of me", "more true of me than untrue", "more untrue of me than true", "untrue of me", "very untrue of me". The scale is divided into four sub-scales: Advantages, Caring Tendency, Gender Advantage, and Employment Security. The students' attitudes towards the reputation of female and male teachers is measured with three statements assessed using a 5-point Likert scale with the response anchors: "strongly agree", "agree", "neither agree nor disagree", "disagree", "strongly disagree". In addition, questions regarding the student's personal characteristics, the context of their parents' place of birth and education, as well as the language used at home are included in the questionnaire.

Data Collection and Analysis: The questionnaire was first piloted with five students from the same faculty to receive their feedback on the clarity of the questions and scales, as well as to assess the amount of time required to complete 
the questionnaire. The paper versions were than hand-delivered at faculty lectures, where they were completed and collected.

Exploratory factor analysis (EFA) was carried out on the data to establish the structural validity and reliability of the scales. Based on the EFA results, the scales were modified, aggregate variables were formed, and the final scales were tested for reliability.

Principal component analysis (PCA) was conducted separately on the groups of items from both scales with oblique rotation (oblimin). The KeiserMeyer-Olkin measure (KMO) verified the sampling adequacy for the analysis, $\mathrm{KMO} \geq .75$ (see Table 1), which is "good" according to Field (2009). All of the KMO values for individual items were above the acceptable limit of .5 in both analyses (ibid.). Bartlett's test of sphericity for both analyses indicated that correlations between items were sufficiently large for the PCA. The components that had eigenvalues over Kaiser's criterion of 1 in the initial analysis were retained in the final analysis.

Table 1: Keiser-Meyer-Olkin measure, results of Bartlett's test of sphericity and percentage of total variance explained by the components for the Desirable Employment scale and the Deciding factors scale.

\begin{tabular}{lclc}
\hline Scale & $\begin{array}{c}\text { Keiser-Meyer- } \\
\text { Olkin measure }\end{array}$ & Bartlett's test of sphericity & $\begin{array}{c}\text { \% of total variance explained } \\
\text { by the components }\end{array}$ \\
\hline Desirable Employment & .75 & $\chi^{2}(28)=271.81, p=0.000$ & 57.94 \\
Deciding Factors & .82 & $\chi^{2}(120)=919.08, p=0.000$ & 65.34 \\
\hline
\end{tabular}

Table 2 presents the final loadings after rotation for the Desirable Employment scale. The items that cluster on the same components suggest that component 1 represents Caring and component 2 represents Benefits. Three items had to be removed from the model due to their lowering of the reliability of the sub-scales: "I want a highly paid job", "I want employment that is not emotionally challenging", and "I want employment with a high status in society". The sub-scales of the final two-component model had acceptable reliabilities of .79 and .64. 
Table 2. Summary of exploratory factor analysis results for the Desirable Employment scale.

\begin{tabular}{lcc}
\hline \multirow{2}{*}{ I want employment... } & \multicolumn{2}{c}{ Rotated factor loadings } \\
\cline { 2 - 3 } & Caring & Benefits \\
\hline that will allow me to influence future generations. & .84 & \\
that enables me to contribute to society. & .74 & \\
that enables me to use the knowledge I gained in my study. & .71 & \\
that enables me to work with people. & .70 & \\
that is intellectually challenging. & .68 & .84 \\
that is safe. & & .72 \\
that does not interfere with family life. & & .69 \\
that provides a secure income. & 3.03 & 1.61 \\
\hline Eigenvalues & 37.84 & 20.09 \\
\% of variance & .79 & .64 \\
$\alpha$
\end{tabular}

Note: Principal Component Analysis, with oblimin rotation; factor loadings below .40 were omitted.

The factor analysis of the Deciding Factors scale showed the structure of four components: Advantages, Caring Tendency, Gender Advantage, and Employment Security. Two items were removed due to their low loading to any of the components ("I chose a teaching profession because of its high status in a society" and "I chose a teaching profession because my parents are teachers"). The sub-scales of the final four-component model had good reliabilities of .7 or above. The final loadings after rotation are presented in Table 3.

Table 3. Summary of exploratory factor analysis results for the Deciding Factors scale.

\begin{tabular}{|c|c|c|c|c|}
\hline \multirow[b]{2}{*}{ I chose a teaching profession because... } & \multicolumn{4}{|c|}{ Rotated factor loadings } \\
\hline & Advantages & $\begin{array}{l}\text { Caring } \\
\text { Tendency }\end{array}$ & $\begin{array}{l}\text { Gender } \\
\text { Advantage }\end{array}$ & $\begin{array}{l}\text { Employment } \\
\text { Security }\end{array}$ \\
\hline $\begin{array}{l}\text { teaching is a job that is appealing for } \\
\text { lengthy holidays. }\end{array}$ & .85 & & & \\
\hline $\begin{array}{l}\text { teaching is a job that is appealing for } \\
\text { convenient working days. }\end{array}$ & .80 & & & \\
\hline $\begin{array}{l}\text { teaching is a job that provides relatively } \\
\text { good promotion opportunities. }\end{array}$ & .67 & & & \\
\hline
\end{tabular}




\begin{tabular}{|c|c|c|c|c|}
\hline \multirow[b]{2}{*}{ I chose a teaching profession because... } & \multicolumn{4}{|c|}{ Rotated factor loadings } \\
\hline & Advantages & $\begin{array}{l}\text { Caring } \\
\text { Tendency }\end{array}$ & $\begin{array}{c}\text { Gender } \\
\text { Advantage }\end{array}$ & $\begin{array}{l}\text { Employment } \\
\text { Security }\end{array}$ \\
\hline $\begin{array}{l}\text { teaching is a job that is convenient for } \\
\text { family life. }\end{array}$ & .59 & & & \\
\hline $\begin{array}{l}\text { I will be able to contribute to better life } \\
\text { in society. }\end{array}$ & & .86 & & \\
\hline I want to help others. & & .83 & & \\
\hline $\begin{array}{l}\text { I like to learn and pass on knowledge } \\
\text { to others. }\end{array}$ & & .72 & & \\
\hline I like working with children. & & .69 & & \\
\hline $\begin{array}{l}\text { I will be able to influence the opinions } \\
\text { of others. }\end{array}$ & & .51 & & \\
\hline it is recognised as typical for women. & & & .84 & \\
\hline $\begin{array}{l}\text { I will be privileged because of my } \\
\text { gender. }\end{array}$ & & & .83 & \\
\hline $\begin{array}{l}\text { I want to become a head teacher one } \\
\text { day. }\end{array}$ & & & .71 & \\
\hline teaching provides a secure job. & & & & -.74 \\
\hline it provides a job for an indefinite period. & & & & -.66 \\
\hline $\begin{array}{l}\text { it provides good employment oppor- } \\
\text { tunities. }\end{array}$ & & & & -.66 \\
\hline Eigenvalues & 5.34 & 2.65 & 1.45 & 1.02 \\
\hline$\%$ of variance & 33.37 & 16.55 & 9.03 & 6.38 \\
\hline$\alpha$ & .85 & .77 & .73 & .79 \\
\hline
\end{tabular}

Note: Principal Component Analysis, with oblimin rotation; factor loadings below .40 were omitted.

In order to ensure that the impact of the independent variables was as isolated as possible, we formed categories of the independent variables gender and study programme as follows. Since the Primary Education group of students consisted only of female students, only the data for the Two-Subject Teacher group were tested for differences in the sub-scale scores and individual items' scores according to gender. For the same reason, only data of the female participants were tested for differences related to study programme.

Sub-scale and individual items' average scores and standard deviations are presented along with the values of the Mann-Whitney test for the significant differences in scores related to gender and study programme $(\mathrm{p} \leq .05)$. 


\section{Results}

\section{Desirable characteristics of students' future employment}

The students in our study expressed the high importance of the security of their future employment, as demonstrated by a high general score on the Benefits sub-scale (mean $=4.53, \mathrm{SD}=.52)$. In general, students also want to get a job that allows them to serve society and impact future generations (Caring sub-scale mean $=4.05, \mathrm{SD}=.64$ ). There were no statistically significant differences between female and male students; however, the female students in our sample generally expressed a higher level of expression regarding both the desire for secure employment and for employment that will enable them to contribute to society (see Figure 1).

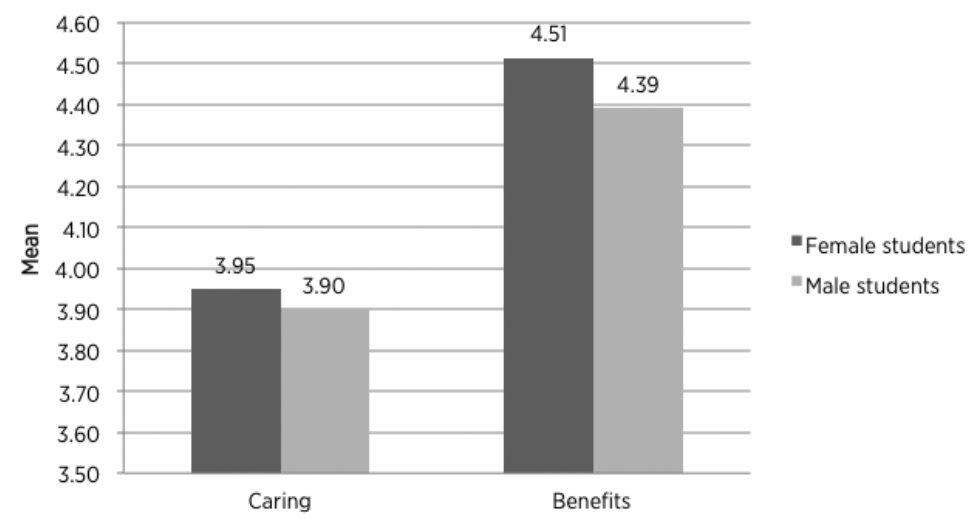

Figure 1: Desirable Employment 5-point sub-scale scores for female and male students.

With regard to study programme, the Primary Education students' scores on both sub-scales are higher than those of the Two-Subject Teacher students (see Figure 2). However, the differences in scores proved to be statistically insignificant. 


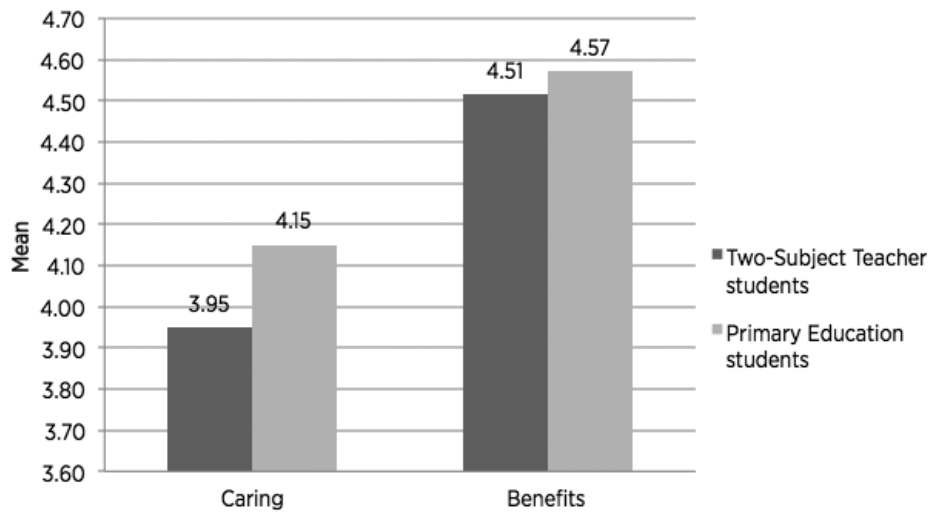

Figure 2: Desirable Employment 5-point sub-scale scores for Primary Education students and Two-Subject Teacher students.

\section{Deciding factors in students' choice of a teaching profession}

Impacting younger generations and being there for others proved to be the most widely expressed deciding factor for choosing a teaching profession among students (Caring Tendancy sub-scale mean $=4.67, \mathrm{SD}=.80$ ). Employment Security appears to be a generally less important factor (mean $=3.38, \mathrm{SD}=1.13$ ), followed by advantages (mean $=3.03, \mathrm{SD}=1.04$ ), while the fact that teaching is a highly gendered profession is not among the deciding factors for choosing this profession $($ mean $=1.95, \mathrm{SD}=.98)$.

There were no statistically significant differences in any of the sub-scales according to gender. However, male students in the sample though did score more highly on all four sub-scales (see Figure 3).

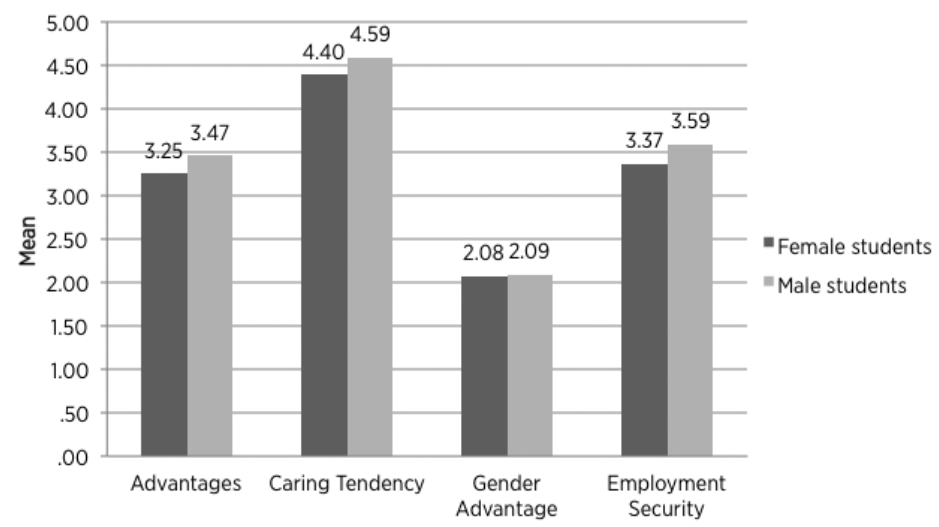

Figure 3: Deciding Factors 6-point sub-scale scores for female and male students. 
On the other hand, Caring Tendency is generally a significantly more important reason for choosing a teaching profession among the Primary Education students (mean $=4.88$ ) than among the Two-Subject Teacher students (mean = 4.40), $U=934.00, z=-3.70, p<.001$. Advantages, however, are generally a significantly more important deciding factor for the Two-Subject Teacher students $($ mean $=3.25)$ than the Primary Education students (mean $=2.75), \mathrm{U}=1116.50, \mathrm{z}=$ $-2.64, p<.01$ (see Figure 4). In terms of the sample, the same trend of differences applies to Employment Security (as well as Gender Advantage).

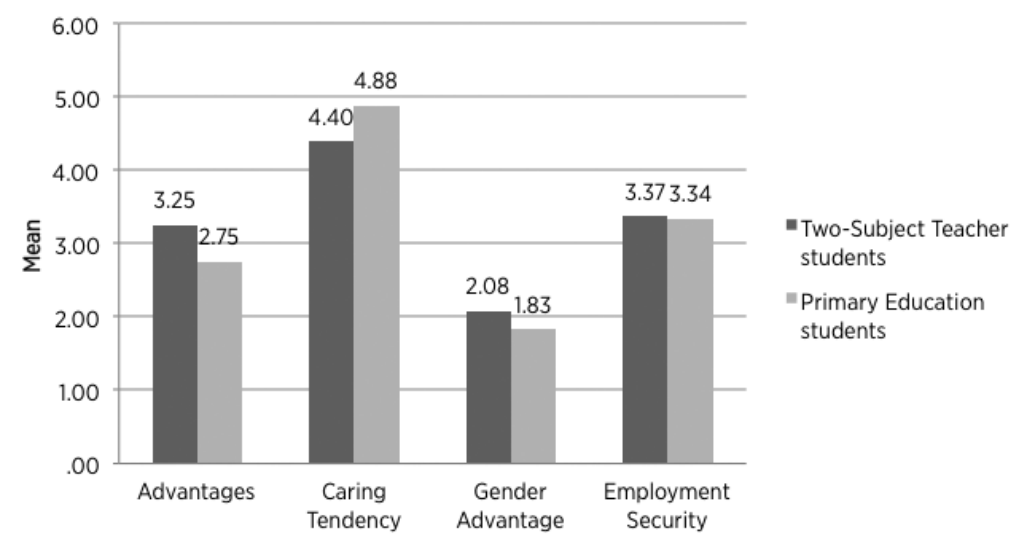

Figure 4: Deciding Factors 6-point sub-scale scores for Primary Education students and Two-Subject Teacher students.

\section{Students on teachers' gender and reputation}

Male students agree significantly more with the statement "Male teachers enjoy more respect among their pupils than their female colleagues", mean = 3.50 ) than female students (mean $=2.68), U=208.50, z=-2.083, p<.05$. In terms of the sample, male students also agree more with statement "Male teachers enjoy more respect among their colleagues than female teachers" (mean $=3.17$ ) than female students (mean $=2.84$ ). Both male and female students in the sample generally disagree with the statement "The female teacher profession is less respected in society than the male teacher profession"; mean $=2.38$ ). 


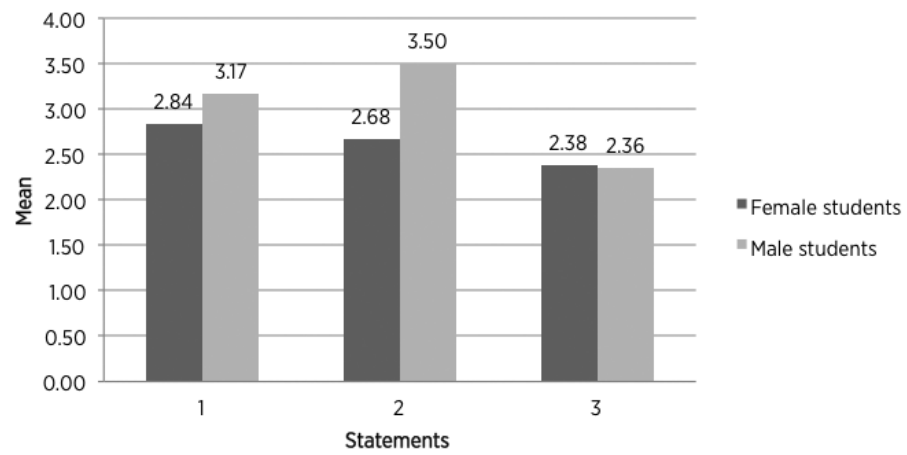

Note: 1 - Male teachers enjoy more respect among their colleagues than female teachers; 2 - Male teachers enjoy more respect among their pupils than their female colleagues; 3 - The female teacher profession is less respected in society than the male teacher profession.

Figure 5: Teachers' gender and reputation 5-point Likert scale scores for female and male students.

The female students of both study programmes do not differ significantly in their agreement with any of the three statements. However, the Primary Education students generally agree more than the Two-Subject Teacher students with statements 1 and 2 regarding male teachers enjoying more respect among their colleagues and pupils in comparison to female teachers (see Figure 6). Finally, the students of the different study programmes in the sample do not differ in their agreement with statement 3; they generally disagree with the statement "The female teacher profession is less respected in society than the male teacher profession".

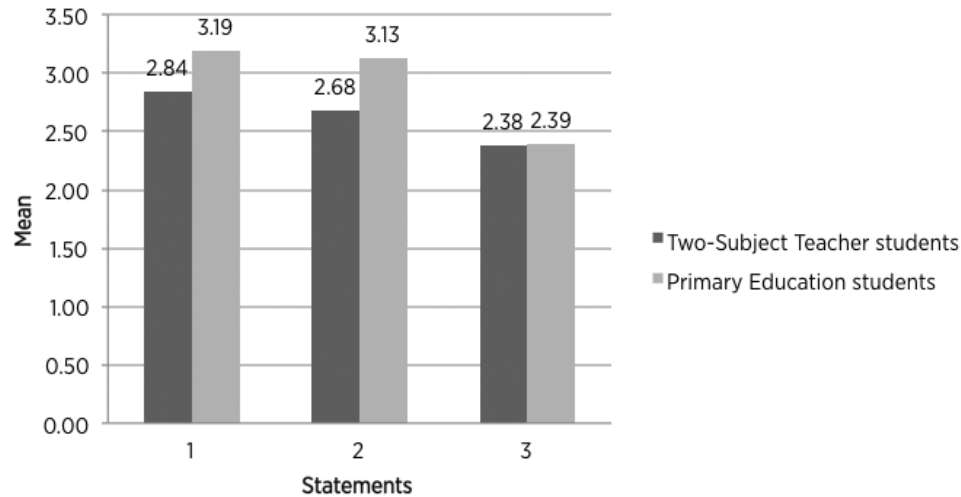

Note: 1 - Male teachers enjoy more respect among their colleagues than female teachers; 2 - Male teachers enjoy more respect among their pupils than their female colleagues; 3 - The female teacher profession is less respected in society than the male teacher profession.

Figure 6: Teachers' gender and reputation 5-point Likert scale scores for Primary Education students and Two-Subject Teacher students. 


\section{Discussion}

The collected data confirmed the known fact that mainly women decide to enter the teacher profession, a pattern that is present in certain other professions in the field of arts, the humanities, services, healthcare and administrative sciences. This was reflected by the fact that there were no men in the Primary Education group. For the majority of the respondents, this was also their first choice of studies.

The numerical predominance of women in education professions, especially those designed for the youngest children, is usually explained as an effect of the conviction that teaching should be regarded as an extension of adults' work with their own children, which is still performed more often by women than men. The importance assigned to the possibility for harmonisation of professional and domestic work by the respondents in our survey is also related to the gender division of labour. Furthermore, it is precisely this characteristic of the occupation that is regarded as one of the most desirable characteristics of the students' future occupation, as well as one of the most important advantages of the teaching profession. Thus, the educational and professional choices made by our respondents are constituted in accordance with their habitus and the practices managed by it (Bourdieu, 1990; 2001). Asimaki and Verdigis conclude with regard to pedagogical studies in Greece - and it is similar in the case of Slovenia - that successful recruiting of a "suitable clientele" into pedagogical professions is taking place: "a clientele whose habitus harmoniously meet the gender character of the particular scientific field" (2013, p. 149).

The numerical predominance of women in education professions can partly be explained by social background, as well. The majority of the respondents came from comparatively small settlements or villages, their parents had mainly completed secondary or professional education, their fathers were mostly employed in the technical field in the private sector, while their mothers were active in the public sector. On this basis, one might conclude, as exposed by Key (2001) in Ferrie, Riddell and Stafford (2006, p. 43), that "middle-class women have moved into certain professional occupations such as law and medicine, whilst undergraduates from poorer backgrounds continue to pursue careers in traditionally female professions such as teaching". It can perhaps be said that teaching offers the possibility of social mobility and security to male and, above all, female students originating from socially weaker surroundings. This conclusion is based on the fact that the teaching profession is a comparatively well-paid profession in Slovenia and the occupation itself is relatively secure, given that the vast majority of (primary and secondary) schools are state schools. The teaching profession is 
perceived as secure despite the fact that we are witnessing an increase in precarious employment, as well as a decrease in public funding for education that has lasted several years. The fact that, on the scale investigating the most desirable characteristics of their future employment, the respondents (on average) ranked a regular income in first place - followed by the possibility of aligning profession life with family life and security of employment - implies that social security is a very important factor in the decision to enter a teaching profession. Although this sequence applies to all three categories of our respondents, it is indicative that these characteristics are most desired among female students of Primary Education, followed by female students of Two-Subject Teacher programmes, and only then by male students. It should, however, be pointed out that these characteristics are not among the most important factors influencing the choice of a teaching profession: all three categories of the respondents did, on average, state factors defined as caring (working with children, helping other people, contributing to the society) as the most important ones. The non-compliance of the results between the two scales could indicate that the choice of a teaching profession is mostly interpreted by the respondents in accordance with the prevailing perception of the teaching profession (especially in the first grades of primary school) as a vocation. In saying this, we are not aiming to manipulate the results, but rather to interpret them according to Beauvois (2000), who demonstrates that people do not have a direct insight into the assertions and causes of their deeds, and in fact do not evaluate the causes but the meanings and values of actions on the basis of social norms. This applies particularly to actions and choices of great social significance, which certainly applies to working with children.

Based on the above results, we can conclude that the idea of vocation (calling) controls the teaching professions to a particularly strong extent in primary education. In choosing the teaching profession, the female Primary Education students did, on average, assign a statistically significantly higher impact to so-called caring factors (i.e., preferences for working with children, contributing to community life, influencing other people's opinion, helping others) than their colleagues attending the Two-Subject Teacher programme, with the difference being even greater in comparison with their male coevals. Furthermore, the meaning attributed to the advantages of the profession (i.e., long vacations, favourable working schedule, opportunities of promotion) is significantly lower than in the case of their coevals of both genders attending the Two-Subject Teacher programme.

Attention should further be drawn to the difference between the male and female respondents (Two-Subject Teacher programme students), which was the only difference to prove statistically significant: male students agree to a 
statistically significantly higher degree with the statement that "Male teachers enjoy more respect among their pupils than their female colleagues" than female students. In terms of the sample, the male students agreed more with the statement about male teachers having a higher status among colleagues, as well. Much like their male colleagues attending the Two-Subject Teacher programme, the female students of the Primary Education programme also agreed with this statement, which may imply a certain level of discomfort due to the symbolic status of their profession. On the other hand, the sample displays a trend that men, on average, feel better positioned in relation to women in the teachers' profession overall, which could also influence the differences in their expectations with regard to their own status in a profession that is still regarded as a "female" profession.

\section{Limitations}

In this paper, we present the results of a pilot study among Primary Education and Two-Subject Teacher students. The study therefore has several obvious limitations. It was carried out at a faculty of education, which possibly triggered socially desirable responses to a certain extent. The second limitation originates from the structure of the sample. The participants from the group of Primary Education students were all female students, which means that the results for this group cannot be generalised to the whole generation of students from the Primary Education study programme at the faculty. On the other hand, the TwoSubject Teacher students were both male and female. This difference in structure of the two groups violated the grounds for comparing all of the participants according to gender as well as study programme.

The present study resulted in eliminating some of the items from the scales to ensure acceptable reliability. This suggests a need to rephrase some of the items, as well as to construct additional ones in the future development of the questionnaire in order to improve the validity and reliability of the scales.

The questionnaire provided a limited insight into the subject of the research; therefore, qualitative research is planned in order to explain this field in more depth.

\section{Conclusions}

The paper attempts to examine the attitudes of students at the Faculty of Education of the University of Ljubljana in the 2015/16 academic year regarding the desirable characteristics of their future employment as deciding factors influencing their choice of a teaching profession, as well as examining their views of the reputation of female and male teachers. 
The collected data confirmed the thesis that women numerically dominate the analysed field. The reasons for this can be found in the harmonisation of the female respondents' habitus and the field they are entering. The perception, especially among female Primary Education students, of the teaching profession as a vocation (calling) that can be linked to the concepts caring, giving and help, also proved very important. These are activities that are attributed to the female habitus during the very earliest socialisation periods. Furthermore, the data confirm the thesis that the orientation towards life and work balance is closer to our respondents of both genders than the orientation towards the centrality of work (Ferrie, Riddell \& Stafford, 2006). It therefore seems that the teaching profession will continue to be dominated by women for quite some time, which, in our eyes, does not represent a social problem. It could, however, become a problem if it an enforced choice for women, an emergency exit, if such jobs are evaluated with a low symbolic value and if the working conditions deteriorate.

\section{References}

Acker S. (1995). Gender and Teachers' Work. Review of Research in Education, 21(1), 99-162.

Retrieved from http://journals.sagepub.com/doi/pdf/10.3102/0091732X021001099.

Antić Gaber M., Rožman S., \& Selišnik I. (2009). Zagotavljanje enakih pravic moških in žensk

[Assure equal rights of men and women]. In V. Tašner (Ed.), Brez spopada: kultur, spolov, generacij

[Without clash of cultures, genders, generations] (pp. 129-142). Ljubljana: Pedagoška fakulteta

Univerze v Ljubljani.

Asimaki A., \& Vergidis K. D. (2013). Detecting the Gender Dimension of the Choice of the Teaching Profession Prior to the Economic Crisis and IMF (International Monetary Fund) Memorandum in

Greece - A Case Study. International Educational Studies, 6(4), 140-153.

Beauvois J. L. (200o). Razprava o liberalni sužnosti. Analiza podrejanja [Traité de la servitude libérale. Analyse de la soumission]. Ljubljana: Krt.

Bourdieu P. (1990). The Logic of Practice. Cambridge: Polity Press.

Bourdieu P. \& Wacquant L. J. D. (1996). An invitation to Reflexive Sociology. Cambridge: Polity Press. Bourdieu P. (2001). Masculine Domination. Cambridge: Polity Press.

Costa L. R. (2006). The logic of Practices in Pierre Bourdieu. Current Sociology, 54(6), 873-895.

Dillabough J.-A. (2004). Class, culture an the "predicaments of masculine domination": encountering Pierre Bourdieu. British Journal of Sociology of Education, 25(4), 489-506.

Drudy S. (2008). Gender balance/gender bias: the teaching profession and the impact of feminisation. Gender and Education, 20(4), 309-323.

European Commission/EACEA/Eurydice (2015). The Teaching Profession in Europe: Practices, Perceptions, and Policies. Eurydice Report: Luxemburg: Publications Office of the European Union. Ferrie J., Riddell S., \& Stafford A. (2006). Undergraduates' views of teaching as a career. In S. Riddell 
\& L. Tett (Eds.), Gender and Teaching. Where have All the Men Gone? (pp. 32-44). Edinburgh:

Dunedin Academic Press.

Field A. (2009). Discovering statistics using SPSS. London: SAGE Publications.

Krais B. (2006). Gender, Sociological Theory and Bourdieu's Sociology of Practice. Theory, Culture \& Society, 23(6), 119-134.

Milharčič Hladnik M. (1995). Šolstvo in učiteljice na Slovenskem [Education and female teachers in Slovenia]. Ljubljana: Znanstveno in publicistično središče.

Mrgole Jukič T. (1998). »V šolo grem, pa pika!« Izobraževanje deklet v prvi polovici 20. Stoletja ["In school I go!" Education of girls in the first half of $20^{\text {th }}$ century]. In T. Mrgole Jukič (Ed.), Izobraževanje in zaposlovanje žensk nekoč in danes [Education and employment of women - past an present] (pp. 101-131). Ptuj: Zgodovinski arhiv.

Noddings N. (1996). On Community. Educational Theory, 46(3), 245-267.

Noddings N. (1992). The challenge to care in schools. New York: Teachers College Press.

Postone M., Calhoun C., \& Lippma E. (1993). Introduction: Bourdieu and Social Theory. In C.

Calhoun, E. Lippma, \& M. Postone (Eds.), Bourdieu - Critical Perspectives (pp. 1-13). Chicago: UCP

Richardson P. W. \& Watt H. M. G. (2006). Who Chooses Teaching and Why? Profiling

Characteristics and Motivations Across Three Australian Universities. Asia-Pacific Journal of Teacher

Education, 34(1), 27-56.

Riddell S. \& Tett L.( 2006). Gender and Teaching. Where have All the Men Gone? Edinburgh: Dunedin Academic Press.

Statistical Office of the Republic of Slovenia [SORS]. Retrieved February 7, 2017, from http://www.stat.si/StatWeb/prikazi-novico?id=5865\&idp=9\&headerbar=7;

http://pxweb.stat.si/pxweb/Dialog/SaveShow.asp;

http://www.stat.si/StatWeb/prikazi-novico?id=6278\&idp=9\&headerbar=7.

Tašner V., \& Rožman S. (2015). The Influence of Changes in the Field of Education on the Position of Women in Slovenian Society and Politics. In M. Antić Gaber (Ed.), Gender Structuring of

Contemporary Slovenia (pp. 37-54). Frankfurt: Peter Lang.

Walkerdine V. (1990). School girl fictions. London: Verso Press.

Walkerdine V. (1994). Reasoning in a Post-modern Age in Mathematics. In P. Ernest (Ed.), Education and Philosophy: An International Perspective (pp. 61-75). London: Falmer Press. 


\section{Biographical note}

Veronika TAŠner, $\mathrm{PhD}$, is an Assistant for the Sociology of Education at the Faculty of Education, University of Ljubljana. Her work involves research into meritocracy, equality and inequality in education, private education, and gender and education. She has participated in various research projects on the topic of education and its justice and future. She is the author of several articles and chapters in the areas in which she research in Slovene and foreign scientific journals and monographs.

MojCA Žveglič Minelič is an assistant for pedagogical methodology and statistics at the Faculty of Education, University of Ljubljana. She is a PhD student at the same faculty, and is writing a dissertation on methodological views of internal knowledge assessment in primary school. Her research area is educational assessment.

Metka Mencin ČePlak, PhD, is an assistant professor of social psychology, employed at University of Ljubljana, (Slovenia), Faculty for Social Sciences. Her main research interests are the construction of stigmatized identities and (re)production of power relations, gender and youth studies. 